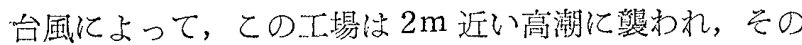
全機能死約 1 力月にわたって停此し，煺業晎 2500 名の

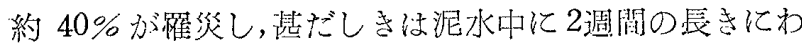
たって孤立するものもあった。10月末にいたり，工場は

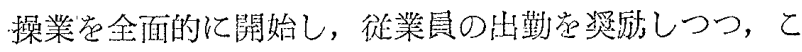

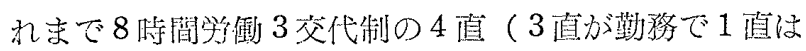

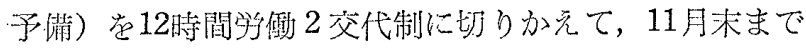
この佮制を続けた。その間，新熀增設工串を加えて生産 飞拍車をかけた。演者は11月末から12月にかけて, 台風

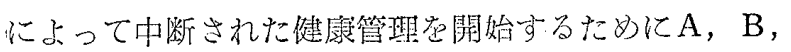

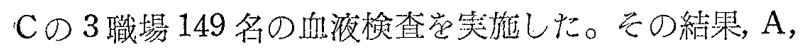
B 2 職場 127 名に执ては䍜災者，非柽災者の区別な

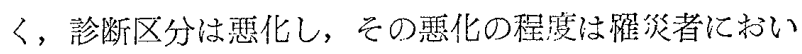
て高かった。とてろが12侍間制からはずされて，従来卢 おりの8 時聞铮衝で, 作業量は推前にくらべて, いくら 加減少していたC職場22名についてみると，非羅災者群

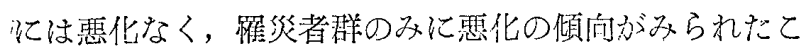
と，かってB，BCであって，4年間の管理により， $\mathrm{AB}^{\prime}$ にまで改善されていたものは例外なく悪化したて とが特徴であった。また，乙の検診の際に，X線技㖞 (羅竾度著明) が，とれまでになく貧血と曰血球減少 (とくに抺中球減少）考示した。悲惨をきわた水害の影 湆と，家庭および工場の復旧に要求された莫大な工ネル ギーの消費とか沙働者の健康に与えた影響省考察する。

\section{8. 硫酸銅液（血液比重測定用）の簡単な検定法}

大内啓子，林美代子，原一郎(大阪府立学研） 硫酸鍼法による血液比重の測定は，産業現場において も簡便に，しかも，ある程度の注意をはらえば相当正確 に行ない得る貧血の検查法であり，学働基準局の特殊健

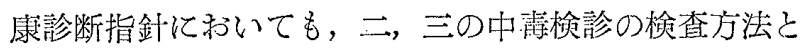
して採用されている。

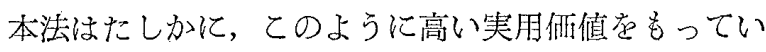
るが，乙の際，用いられる硫酸銅液の比重が正確である ことが前提となる。

しかるに，正確な比重の硫酸銅液の調整は，必らずし も簡笔ではなく，最近，本法の急速な普及の半面，基準

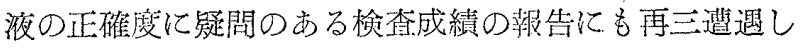
t心o

徒って，簡単かつ正確に硫陵銅液の比重を測定すると とができれば非常に便利である。このための最も簡篻な 方法社比重計（浮科）の便用であるが，一般に市販され ている比霍計は，たとえば 1,000〜1,060 の閵ぶ 1 本の 比重計によって測られるため，ての場合に必要な程度の
精密な測定は不可能である。

そてで，比央計の管部の直径勇比較的小さくする（基 底部にたいする管部の体積の割合在小さくする）ととに より, 比電 1.050〜60 の差, すなわち 0.01 の比重の 差肪，管の目盛において，20〜25mm の差となるよう

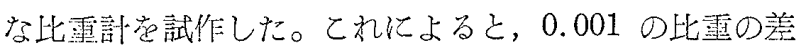
は，2〜2.5mm の長さの差しして示されるので, 充分 美用に供し得る。

もちろん，との比重計の使用にあたっては湿度補正が 必琵であるので，とれに必要な補正表崖作製しや゙。

\section{9. 血墏テロシン法におけるウロペプシンの定量とそ の測定例（冷房時における）}

高木和男, 熄田富江 (学茈・生化学)

ウロペプシンの定戴法としては一般に凝乳法ぶ行なわ れている。この方法は測定が簡监に行ない得るが，一方 測定の都废，標淮液老調製する必要があることが蜼点で あり，またよい標準ペプシンの入手にも問題がある。ウ ロペプシン定活性化した後, ヘモグロビンに作用せしめ 生じたチロシンを定量する方法は Anson, Mirsky, Gray, Westphal，田多井らにより行なわれているが， われわれが追試した結果，Folin 試案によるチロシンの 定最法に難点があること势認けので，ての点在改良し たので，ここに発表する。

基質として用いる血瀪は，日本蛋白 $\mathrm{KK}$ 製造の苑燥血 漿 $2 \mathrm{~g}$ 学 $0.1 \mathrm{NHCl} 90 \mathrm{~m} l$ に潈解し, $\mathrm{pH} 2.0$ とした溶 液である。 $\mathrm{pH} 1.5$ 亿調整した 2 仿稀秎尿 $4.0 \mathrm{~m} l$ 党, 上記基貿浴液 $5 \mathrm{~m} l$ と混和, $37^{\circ} \mathrm{C}$ の恒温槽に正確に 2

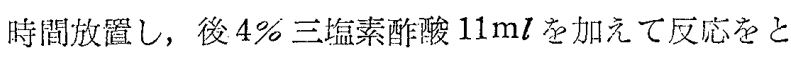
どめ, さらに15分間 $37^{\circ} \mathrm{C}$ に较置する。遠沈して上澄 $2 \mathrm{~m} l$ 芷々り, 水 $2 \mathrm{~m} l, 0.1 \%$ ニトロソナフトール液

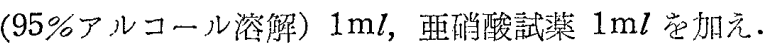
$55^{\circ} \mathrm{C} 30$ 分温浴, 発色せして, 冷後, エチンンシクロラ

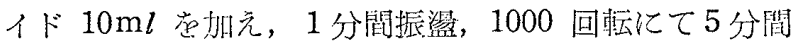

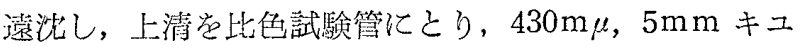

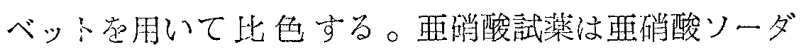
$0.1 \%$ 溶液と，1:2 硝酸溶液と炭使用にあたり，同是 混合して用いる。

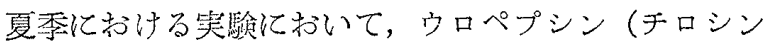

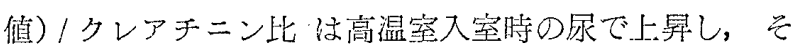
の直後の冷原室入室時の尿で下降する傾沟がみられる。 な赫人差もかなり認わられる。 